\title{
Penulisan Fiksi Sebagai Wahana Artikulasi Gagasan Generasi Muda
}

\author{
Agusniar Rizka Luthfia ${ }^{1)}$ Eka Nada Shofa Alkhajar ${ }^{2)}$,Sonhaji ${ }^{3)}$ Desiderius Priyo \\ Sudibyo $^{4)}$ dan Wahyu Nurharjadmo ${ }^{5)}$
}

\author{
Program Studi Ilmu Administrasi Negara, Fakultas Ilmu Sosial dan Ilmu Politik, \\ Universitas Sebelas Maret, Indonesia ${ }^{1), 3), 4), 5)}$ \\ Program Studi Ilmu Komunikasi, Fakultas Ilmu Sosial dan Ilmu Politik, \\ Universitas Sebelas Maret, Indonesia ${ }^{2)}$ \\ Pos-el: agusniar@staff.uns.ac.id
}

\begin{abstract}
Abstrak
Masa remaja dikenal sebagai masa kritis dan penuh dinamika. Pada periode ini, remaja pun memiliki energi yang melimpah. Energi ini tentu harus dapat disalurkan ke arah yang tepat karena jika tidak energi tersebut berpotensi disalurkan ke arah yang salah. Kegiatan pengabdian kepada masyarakat berupa pelatihan penulisan karya tulis fiksi adalah salah satu sarana untuk menyalurkan energi yang dimiliki remaja. Kegiatan pengabdian kepada masyarakat ini dilaksanakan dengan metode ceramah, metode diskusi, metode pendampingan dan metode praktik. Para remaja mengikuti kegiatan pengabdian dengan antusiasme yang tinggi. Hasil yang dicapai dari kegiatan pengabdian kepada masyarakat ini adalah para remaja yang juga merupakan santri memiliki kemampuan untuk menuliskan ide, gagasan dan kreativitas mereka ke dalam bentuk karya tulis fiksi.
\end{abstract}

Kata Kunci: remaja, pelatihan menulis, fiksi

\begin{abstract}
Adolescence is known as a critical and dynamic period. At this period, adolescents also have abundant energy. This energy certainly needs to be channeled to the right way or otherwise it potentially turned into the wrong way. The community devotion in the form of fiction writing training is one of the ways to channel the adolescent energy. It carried out with lectures, discussions, accompaniments and practices methods. The target of community devotion joined the training with great enthusiasm. The result achieved from this community devotion is that the target of community devotion became able to write uptheir ideas and creativities in the form of fiction.
\end{abstract}

Keywords:adolescent, writing training, fiction

\section{PENDAHULUAN}

Generasi muda adalah aset berharga dan bagian dari tak terpisahkan dari sebuah bangsa. Mereka adalah penerus estafet perjalanan dan kelangsungan hidup sebuah bangsa ke depan. Di tengah perkembangan zaman yang luar biasa cepat seperti sekarang tentu diperlukan hadirnya generasi muda yang tidak hanya pandai secara keilmuan tetapi juga baik secara budi pekerti. Remaja sebagai generasi muda jelas mempunyai peran strategis dan signifikan bagi perkembangan sebuah bangsa (Alkhajar, 2014; Luthfia et al., 2019). Meskipun demikian, masa remaja seperti disampaikan oleh beberapa ahli merupakan sebuah masa kritis dan penuh pergolakan karena masa ini adalah fase transisi dari anak-anak menuju dewasa (Santrock, 2010; Sarwono, 2011). 
Salah satu aspek menarik dari remaja adalah mereka memiliki energi yang berlimpah. Energi ini tentu harus diarahkan ke arah yang positif agar memberikan dampak yang positif pula. Remaja jelas membutuhkan penyaluran energi yang melimpah tersebut. Untuk itu diperlukan sebuah wadah yang tepat untuk menyalurkan energi tersebut. Mengapa? Karena jika tidak, energi yang melimpah ini berpotensi salah arah menuju ke arah negatif yang merusak. Hal ini tentu tidak kita inginkan bersama. Apalagi fakta-fakta telah menyebutkan banyak remaja terjerumus ke arah yang tidak benar seperti tawuran, narkoba, miras, pergaulan bebas dan lain sebagainya.

Anak yatim adalah bagian dari generasi muda penerus bangsa. Dan kita sebagai bagian dari masyarakat telah diamanatkan untuk bisa memuliakan anak yatim dengan memberikan dukungan maupun pendidikan yang berkaitan dengan pengetahuan (Muhsin, 2003; Dasuki, 2011; Chomaria, 2014). Salah pondok pesantren yang memberikan perhatian khusus kepada anak yatim adalah Pondok Pesantren Rumah Senyum Yatim Indonesia (SETIA). Sebagaimana diketahui, sebagian dari para santri yang menjadi binaan di pondok pesantren tersebut sudah menginjak fase remaja. Sebuah fase yangdikatakan Santrock (2010) sebagai sebuah masa yang penuh badai dan stress.

Oleh karena itu, mereka perlu mendapatkan input-input berharga tentang bagaimana menyalurkan energi dan kreativitas yang mereka miliki agar menjadi sesuatu yang bermanfaat. Dari informasi yang didapatkan pada saat melakukan analisis situasi, para remaja tersebut menginginkan adanya sebuah kegiatan dalam bidang penulisan fiksi karena kegiatan semacam ini belum pernah dilakukan sebelumnya. Hal ini tentu menjadi sebuah peluang berharga bagi kami selaku tim pengabdian kepada masyarakat untuk menyelenggarakan sebuah pelatihan penulisan karya tulis fiksi.

Seperti diungkapkan seorang pakar, menulis adalah salah satu jalan untuk menyalurkan energi dan kreativitas ke arah yang positif. Lebih jauh, menulis bahkan bisa menjadi sebuah terapi penyembuhan untuk tekanan batin (Pennebaker, 2007). Berdasarkan latar belakang tersebut maka kegiatan pengabdian kepada masyarakat ini dilaksanakan. Kegiatan ini diharapkan dapat menumbuhkan minat mitra kegiatan untuk menulis dan menghasilkan karya tulis fiksi yang bisa menginspirasi banyak remaja lain. Mereka nantinya diharapkan dapat menularkan semangat positif tersebut kepada generasi muda lainnya karena mereka dan generasi muda lainnya adalah generasi penerus bangsa ke depan.

\section{METODE}

Sebelum kegiatan pengabdian kepada masyarakat ini dilaksanakan, tim pengabdian terlebih dahulu melakukan survei dan koordinasi secara intens dengan pembina dan pengajar di lokasi mitra kegiatan. Hal ini dilakukan untuk menggali kebutuhan dari mitra kegiatan sehingga pelaksanaan kegiatan pengabdian dapat tepat sasaran. Setelah seluruh tahapan termasukpersiapan selesai dilalui maka kegiatan pengabdian segera dilaksanakan. Kegiatan pengabdian kepada masyarakat ini dilaksanakan di Pondok Pesantren Rumah Senyum Yatim Indonesia (SETIA) Unit Putri yang berada di Sukoharjo. Kegiatan ini diselenggarakan di Aula Pondok Pesantren pada 18 Agustus 2019hingga 23 Agustus 2019. Adanya rentang waktu tersebut berkaitan dengan alokasi waktu pemberian materi mengenai karya tulis fiksi 
dan praktik penulisan karya tulis fiksi. Adapun beberapa metode yang digunakan dalam kegiatan pengabdian ini antara lain: metode ceramah, metode diskusi, metode pendampingan dan metode praktik. Metode-metode tersebut dipilih dan digunakan sesuai dengan kemanfaatannya dalam pelaksanaan pelatihan penulisan karya tulis fiksi tersebut. Sementara itu, jumlah peserta yang mengikuti kegiatan pengabdian ini adalah 55 orang.

\section{HASIL DAN PEMBAHASAN}

Secara garis besar kegiatan pengabdian ini menggunakan pendekatan teori dan praktik. Oleh karena itu, kegiatan pengabdian dilaksanakan secara bersambung pada 18 Agustus 2019 hingga 23 Agustus 2019. Pelaksanaan hari pertama difokuskan pada pemberian pengetahuan dan pemahaman tentang dasar-dasar kepenulisan karya tulis fiksi. Pada kesempatan ini para santri diberikan pemahaman bahwa menulis karya tulis fiksi adalah sebuah kegiatan yang menyenangkan sebagai sarana untuk menuangkan ide, gagasan dan pengalaman keseharian yang ada (Luthfia dan Alkhajar, 2011). Mereka diberikan motivasi untuk terus meningkatkan semangat menulis melalui sesi-sesi pemaparan materi, seperti berkaitan dengan rasionalisasi mengapa harus menulis, masalah klasik ketika menulis, bagaimana cara mengawali untuk menulis, inti terpenting proses kreatif menulis hingga langkah-langkah mencari, mematangkan dan menuliskan ide dan gagasan ke dalam bentuk tulisan.

Selain itu, mereka juga dibekali pengetahuan tentang bagaimana cara mengatasi kebuntuan ketika sedang menulis atau dikenal sebagai writer's block. Hal ini penting karena seorang penulis pemula sangat berpotensi terkena kebuntuan menulis. Persoalan ini bahkan juga bisa menimpa para penulis hebat, hanya saja mereka sudah sangat memahami bagaimana cara mengatasinya. Lebih jauh, para santri juga dibekali pengetahuan mengenai teknik menyunting tulisan yang telah mereka dihasilkan seperti merapikan dan menghaluskan sehingga kualitas tulisan menjadi semakin baik.

Setelah pemberian materi berakhir, para santri masuk ke tahap praktik penulisan. Ini adalah aspek penting karena tanpa praktik maka hasil kegiatan pengabdian ini tidak akan optimal. Terlebih menulis karya tulis fiksi adalah persoalan untuk praktik menuangkan gagasan sehingga menjadi sebuah bentuk karya tulis. Oleh karena itu, seluruh peserta diwajibkan untuk membuat minimal satu karya tulis di mana mereka diberikan kebebasan untuk memilih bentuk penulisan yang mereka senangi. Praktik penulisan ini dilaksanakan dalam rentang waktu 19 Agustus sampai 22 Agustus 2019. Karya-karya tulis mereka ini kemudian dibahas dan dievaluasi bersama pada 23 Agustus 2019. Selama rentang waktu ini para santri mendapatkan pendampingan untuk menuliskan ide dan gagasan mereka ke dalam bentuk tulisan. Mereka diberikan kesempatan dan keleluasaan untuk berkomunikasi dan berkonsultasi berkenaan dengan praktik penulisan karya tulis fiksi sehingga mereka terus bersemangat untuk menyelesaikan karya tulisnya.

Sesuai dengan tahapan agenda kegiatan, seluruh karya tulis fiksi ini kemudian dibahas dan dievaluasi bersama pada 23 Agustus 2019. Pada kesempatan ini para santri mendapatkan umpan balik berupa masukan-masukan atas karya tulisnya. Selain itu, mereka juga bisa berkonsultasi secara langsung untuk memperbaiki karya tulisnya. Dari hasil evaluasi terhadap karya tulis yang telah dihasilkan kebanyakan para santri memilih untuk untuk menulis cerita anak dan cerita pendek. Semangat dan minat mereka dalam mengikuti kegiatan pengabdian 
bisa dikatakan tinggi. Hal ini terbukti dari banyaknya hasil karya yang telah mereka hasilkan. Di antara mereka bahkan ada yang menulis lebih dari satu tulisan.

Secara umum pelaksanaan kegiatan pengabdian berjalan dengan baik dan lancar tanpa ada kendala yang berarti. Para santri yang notabenenya merupakan remaja ini bisa dikatakan telah memiliki keterampilan untuk menuangkan ide, gagasan dan kreativitas mereka ke dalam bentuk karya tulis fiksi. Ini dapat dilihat dari karya-karya yang telah mereka hasilkan. Kegiatan pengabdian ini memang diarahkan untuk membekali remaja agar memiliki keterampilan menulis. Meskipun demikian, kegiatan pengabdian ini juga dimaksudkan untuk menyadarkan remaja akan peran penting mereka untuk ikut membangun bangsa melalui halhal positif yang dapat mereka lakukan. Para remaja ini diharapkan memiliki kesadaran kritis dan tidak terjebak pada realitas semu sehingga mereka menjadi semakin tangguh dalam menjalani kehidupan nyata serta mampu memberikan kontribusi positif terhadap lingkungan yang ada di sekitar mereka (Alkhajar, 2007).

\section{SIMPULAN}

Kemampuan untuk mengartikulasikan ide dan gagasan dalam bentuk tulisan adalah sesuatu yang penting untuk dimiliki setiap orang. Hal itu penting karena melalui tulisan seseorang dapat menyampaikan ide dan gagasannya kepada khalayak yang lebih luas. Para santri yang mengikuti kegiatan pengabdian ini memperoleh bekal kemampuan untuk menulis berupa dasar-dasar teori dan praktik penulisan karya tulis fiksi. Dengan bekal pengetahuan dan keterampilan ini mereka dapat menyalurkan minat dan bakatnya dalam bidang tulismenulis. Respon dan umpan balik terhadap pelaksanaan kegiatan pengabdian dari para santri juga positif dan menggembirakan. Mereka intens mengikuti setiap tahapan kegiatan pengabdian dengan penuh semangat dan antusiasme yang tinggi. Para santri pun berharap agar kegiatan sejenis ini dapat dilaksanakan kembali di tempat mereka di masa yang akan datang. Para santri menilai kegiatan pelatihan menulis karya tulis fiksi seperti ini sangatmenarik dan bermanfaat bagi mereka.

\section{UCAPAN TERIMA KASIH}

Kami mengucapkan terima kasih atas dukungan penuh dari pihak mitra terutama Bapak Muhammad Doby dan Ibu Endang Komalasariselaku pembina dan pengajar di Pondok Pesantren Rumah SETIA sehingga kegiatan pengabdian dapat terlaksana dengan baik dan lancar. Tak lupa, kami juga mengucapkan terima kasih kepada para santri atas semangat, partisipasi dan antusiasmenya dalam mengikuti kegiatan pengabdian ini.

\section{DAFTAR PUSTAKA}

Alkhajar, Eka Nada Shofa. 2007. "Hiperealitas dalam Kehidupan Nyata." Kompas, 31 Desember.

Alkhajar, Eka Nada Shofa. 2014. Media, Masyarakat dan Realitas Sosial. Surakarta: Sebelas Maret University Press.

Chomaria, Nurul. 2014. Cara Mencintai Anak Yatim. Solo: Aqwam.

Dasuki, Muhd. Nasruddin. 2011. 100 Pesanan Terakhir Rasulullah. Selangor: Grup BukuKarangkraf. 
Luthfia, Agusniar Rizka, and Eka Nada Shofa Alkhajar. 2011. Pelabuhan Terakhir. Surakarta: Bukutujju.

Luthfia, Agusniar Rizka, Nurhayatu Nufut Alimin, Febriani Sarwendah Asri Nugraheni, Eka Nada Shofa Alkhajar. 2019. "Penguatan Literasi Perubahan IklimdiKalangan

Remaja." Abadimas Adi Buana, 3(1): 39-42.

Muhsin M.K. 2003. Mari Mencintai Anak Yatim. Jakarta: Gema Insani Press.

Pennebaker, James W. 2007. Opening Up: The Healing Power of ExpressingEmotions. New York: Guilford Press.

Santrock, John W. 2010. Adolescence. New York: McGraw-Hill.

Sarwono, Sarlito Wirawan. 2011. Psikologi Remaja. Jakarta: PT. Raja GrafindoPersada. 